Article

\title{
Isolation and Characterization of 13 Microsatellite Loci from a Korean Endemic Species, Sophora koreensis (Fabaceae)
}

\author{
Ji-Yeon Lee ${ }^{1,2}$, Dong-Hyuk Lee ${ }^{1}$ and Byoung-Hee Choi ${ }^{1, *}$ \\ 1 Department of Biological Sciences, Inha University, Incheon 402-751, Korea; \\ E-Mails: leejiyeon@korea.kr (J.-Y.L.); dongh12345@hanmail.net (D.-H.L.) \\ 2 Plant Resources Division, National Institute of Biological Resources, \\ Incheon 404-708, Korea \\ * Author to whom correspondence should be addressed; E-Mail: bhchoi@inha.ac.kr; \\ Tel.: +82-32-8607695; Fax: +82-32-8746737.
}

Received: 3 August 2012; in revised form: 21 August 2012 / Accepted: 21 August 2012 / Published: 28 August 2012

\begin{abstract}
To evaluate the population genetics structure as a means of devising conservation strategies, we developed microsatellite primers for Sophora koreensis, a narrowly endemic and endangered species in Korea. Thirteen polymorphic microsatellite markers were developed in Korean populations of $S$. koreensis. Genetic diversity was analyzed in 40 individuals from two populations. The number of alleles per locus ranged from 4 to 14, with observed and expected heterozygosities ranging from 0.200 to 1.000 and from 0.189 to 0.864 , respectively. The microsatellite markers described here are valuable tools for the population genetics research of $S$. koreensis. They can be used to obtain information for creating suitable management strategies to conserve this endemic and endangered species.
\end{abstract}

Keywords: endemic species; genetic diversity; microsatellite; Sophora koreensis

\section{Introduction}

Sophora koreensis Nakai (Fabaceae) is a deciduous small shrub. Narrowly endemic, it is found at only a few locations in central Korea. Plants grow in dry soil in the understory of Pinus and Quercus forests. The shoots are interconnected by rhizomes, and propagation occurs both sexually (e.g., pollinated by the bumblebee Bombus diversus diversus) and vegetatively [1]. It is listed as an "Endangered Species" in 
the Rare Plant Data Book in Korea [2]. Based on its characteristics of four-winged legumes and vegetative propagation from long rhizomes, this species was previously separated from Sophora and categorized within the monotypic genus Echinosophora Nakai [3]. However, taxonomic studies based on pollen and petal morphologies and molecular evidence [4-6] have found that Echinosophora cannot be so clearly distinguished. Therefore, it is now treated again as a species within Sophora [7].

Numerous studies have indicated that narrowly endemic plants are susceptible to extinction for several reasons, one of the most important being habitat destruction [8]. In the case of S. koreensis, those populations are at risk from illegal plant collectors and projects such as trail or road construction. Despite the increasing demand for preservation and management plans, no suitable high-resolution genetic data have been available for this species. A population genetics study using dominant ISSR markers was performed to investigate the clonal and spatial genetic structures of $S$. koreensis [1]. However, those results were limited because the use of dominant markers does not allow scoring of genotypes. Heterozygosity is a more consistent measure, incorporating both total allelic diversity and the distribution of alleles among individuals that are affected by factors such as inbreeding and assortative mating [9]. Therefore, we have now developed a set of polymorphic and co-dominant microsatellite markers for $S$. koreensis that can serve as effective genetic markers. By conducting further assessments of its genetic diversity and population structure, we can strive toward establishing a strategy for its conservation.

\section{Results and Discussion}

We produced 13 polymorphic microsatellite loci that revealed clear and strong bands for each allele across two populations. Genotypic data were obtained for the 40 individuals from Mt. Bibong and Hanjeon-ri. Parameters for genetic diversity within each population are presented in Table 1. Overall, the alleles numbered 4 to 14 (average of 6.9); their observed and expected heterozygosities $\left(H_{\mathrm{o}}\right.$ and $\left.H_{\mathrm{e}}\right)$ ranged from 0.200 to 1.000 and from 0.189 to 0.864 , respectively (Table 1). Four of those 13 loci (Skor7, Skor10, Skor12, and Skor13) showed homozygotes or an excess of heterozygotes within the Mt. Bibong population, with significant deviations from the correction Hardy-Weinberg equilibrium (HWE) after a Bonferroni correction ( $p<0.005$; Table 1). No significant linkage disequilibrium (LD) was detected between locus pairs. These excesses might have been caused by a significantly high frequency of asexual reproduction that maintained heterozygotes or homozygotes over several generations.

Table 1. Results of initial primer screening in Sophora koreensis. $N_{\mathrm{a}}$, number of alleles; $H_{\mathrm{o}}$, observed heterozygosity; and $H_{\mathrm{e}}$, expected heterozygosity. $p$-Values for Hardy-Weinberg equilibrium (HWE) tests are given for each marker.

\begin{tabular}{cccccccccc}
\hline \multirow{2}{*}{ Locus } & \multicolumn{4}{c}{ Mt. Bibong $(\boldsymbol{n}=\mathbf{3 0})$} & \multicolumn{4}{c}{ Hanjeon-ri $(\boldsymbol{n}=\mathbf{1 0})$} \\
\cline { 2 - 4 } \cline { 7 - 10 } & $\boldsymbol{N}_{\mathbf{a}}$ & $\boldsymbol{H}_{\mathbf{0}}$ & $\boldsymbol{H}_{\mathbf{e}}$ & $\boldsymbol{p}$-value & & $\boldsymbol{N}_{\mathbf{a}}$ & $\boldsymbol{H}_{\mathbf{0}}$ & $\boldsymbol{H}_{\mathbf{e}}$ & $\boldsymbol{p}$-value \\
\hline Skor1 & 4 & 0.733 & 0.642 & 0.043 & & 3 & 0.800 & 0.556 & 0.367 \\
Skor2 & 8 & 0.768 & 0.783 & 0.036 & & 4 & 0.600 & 0.611 & 0.213 \\
Skor3 & 4 & 0.367 & 0.375 & 0.495 & & 3 & 0.800 & 0.556 & 0.368 \\
Skor4 & 4 & 0.700 & 0.544 & 0.092 & & 3 & 0.800 & 0.644 & 0.834 \\
Skor5 & 4 & 0.700 & 0.578 & 0.176 & & 2 & 0.800 & 0.489 & 0.176 \\
\hline
\end{tabular}


Table 1. Cont.

\begin{tabular}{|c|c|c|c|c|c|c|c|c|}
\hline \multirow{2}{*}{ Locus } & \multicolumn{4}{|c|}{ Mt. Bibong $(n=30)$} & \multicolumn{4}{|c|}{ Hanjeon-ri $(n=10)$} \\
\hline & $N_{\mathrm{a}}$ & $H_{0}$ & $\boldsymbol{H}_{\mathrm{e}}$ & $p$-value & $N_{\mathrm{a}}$ & $H_{0}$ & $\boldsymbol{H}_{\mathrm{e}}$ & $p$-value \\
\hline Skor6 & 9 & 0.667 & 0.602 & 0.378 & 5 & 1.000 & 0.744 & $0.004^{*}$ \\
\hline Skor7 & 7 & 0.900 & 0.807 & $0.000^{*}$ & 4 & 1.000 & 0.744 & 0.291 \\
\hline Skor8 & 7 & 0.867 & 0.795 & 0.230 & 5 & 0.800 & 0.800 & 0.010 \\
\hline Skor9 & 7 & 0.533 & 0.726 & 0.010 & 6 & 0.800 & 0.717 & 0.133 \\
\hline Skor10 & 13 & 0.933 & 0.864 & $0.000^{*}$ & 5 & 0.800 & 0.761 & $0.003^{*}$ \\
\hline Skor11 & 7 & 0.533 & 0.638 & 0.147 & 3 & 0.200 & 0.367 & 0.007 \\
\hline Skor12 & 4 & 0.267 & 0.571 & $0.000^{*}$ & 2 & 0.200 & 0.189 & 1.000 \\
\hline Skor13 & 6 & 0.467 & 0.699 & $0.000^{*}$ & 4 & 0.400 & 0.661 & 0.044 \\
\hline
\end{tabular}

\section{Experimental Section}

\subsection{Isolation of Microsatellite Markers}

Genomic DNA was extracted with a G-spin ${ }^{\mathrm{TM}}$ IIp Kit for plants (iNtRON, Seongnam, Korea). Microsatellites were developed according to the enrichment protocol [10], but with minor modifications. Briefly, genomic DNA was digested with MboI (Promega, Madison, WI, USA), and the resulting fragments were ligated to SAUL linkers [10] by using the T4 DNA ligase (Promega). Those fragments were then enriched for microsatellites with a cocktail comprising seven biotinylated probes $\left[(\mathrm{AG})_{15},(\mathrm{AT})_{15},(\mathrm{AC})_{15},(\mathrm{ACG})_{10},(\mathrm{AGC})_{10},(\mathrm{CAA})_{10}\right.$, and $\left.(\mathrm{ACAT})_{7}\right]$ that were bound to streptavidin-coated magnetic beads (Promega). This enrichment process was performed twice. The fragments were then amplified and cloned using the $\mathrm{PCR}^{\circledR}$ 2.1-TOPO ${ }^{\circledR}$ vector (Invitrogen, Carlsbad, CA, USA). The size of the insert in 288 clones was evaluated by PCR, using the linker primer, and clones with 400- to 800-bp inserts were selected for sequencing. In all, 240 clones were subjected to double-stranded DNA sequencing that utilized BigDye Terminator version 3.1 and an ABI 3730xl sequencer (Applied Biosystems, Foster City, CA, USA). We culled the primers with short repeat regions or short flanking regions, or those that were close to the vector because they did not fit our criteria. Thirty-eight PCR primer pairs were designed with FastPCR version 5.4.51 software [11]. The M13 (-21) (5'-TGTAAAACGACGGCCAGT-3') sequence-tag method was used to label those primers [12]. Of these 38, 17 failed to amplify, three had complex amplification, and five showed high frequencies of null alleles. Consequently, only 13 primer pairs could be successfully amplified within the expected size ranges. Loci characterizations and GenBank Accession Numbers for these 13 microsatellites are listed in Table 2. 
Table 2. Characteristics of 13 microsatellite markers developed in Sophora koreensis. All forward primers were M13 (5'-TGTAAAACGACGGCCAGT-3')-tailed at the 5' end. Annealing temperature for each round of PCR was $52^{\circ} \mathrm{C}$.

\begin{tabular}{|c|c|c|c|c|}
\hline Locus & Primer sequences $\left(5^{\prime} \rightarrow 3^{\prime}\right)$ & Repeat motif & Size range (bp) & GenBank Accession No. \\
\hline \multirow[t]{2}{*}{ Skor1 } & F: ACTCAAAGCTGGAAGGGT & $(\mathrm{TG})_{13}$ & $251-273$ & JX131650 \\
\hline & R: TTCCGGTTGTTCGAGTCT & & & \\
\hline \multirow[t]{2}{*}{ Skor2 } & F: TGAACTACTACTCCGCTT & $(\mathrm{AG})_{14}$ & $266-292$ & JX131651 \\
\hline & R: ACCCCGTCAGCCAATACTTA & & & \\
\hline \multirow[t]{2}{*}{ Skor3 } & F: ATTCTGACTATTGGGCTAGTG & $(\mathrm{GT})_{20}$ & $222-244$ & JX131652 \\
\hline & R: ATCTGCTAAACCCTTGCTG & & & \\
\hline \multirow[t]{2}{*}{ Skor4 } & F: TCAATCACTATAAGGGTTCAG & $(\mathrm{CAA})_{12}$ & $240-252$ & JX131653 \\
\hline & R: AAGTGTCAGGTGCATAAACC & & & \\
\hline \multirow[t]{2}{*}{ Skor5 } & F: ATCAACTACTTCATGCGC & $(\mathrm{TG})_{14}$ & $260-276$ & JX131654 \\
\hline & R: ACAATCACTCCCAGCATAC & & & \\
\hline \multirow[t]{2}{*}{ Skor6 } & F: ACAAAAAGAAATGGTCGCG & $(\mathrm{CA})_{21}(\mathrm{GA})_{10}$ & $242-294$ & JX131655 \\
\hline & R: ACATGCCCCTCTGCCCCAAC & & & \\
\hline \multirow[t]{2}{*}{ Skor7 } & F: TTGAAAAGTCCCACCTAGC & $(\mathrm{GA})_{26}$ & 273-291 & JX131656 \\
\hline & R: TATCACCGCCAAGAACTTG & & & \\
\hline \multirow[t]{2}{*}{ Skor8 } & F: TCTAGGAGGAAATAGGGAG & $(\mathrm{CA})_{12}$ & $285-297$ & JX131657 \\
\hline & R: TAGACTCTTGGAACAAGAAC & & & \\
\hline \multirow[t]{2}{*}{ Skor9 } & F: TGGACACCCCTTATGGCTG & $(\mathrm{AG})_{19}$ & $248-278$ & JX131658 \\
\hline & R: ACCAAAGATTCCCGTGACAC & & & \\
\hline \multirow[t]{2}{*}{ Skor10 } & F: TTGGGATAGAGTCACGTCC & $(\mathrm{GT})_{11}(\mathrm{GA})_{15}$ & $222-270$ & JX131659 \\
\hline & R: ACCGAACATGTCTCATTACC & & & \\
\hline \multirow[t]{2}{*}{ Skor11 } & F: TAAAGTGCATGTTCCCAG & $(\mathrm{CA})_{10}$ & $256-296$ & JX131660 \\
\hline & R: TGCTGAACCCTTAGAGAGG & & & \\
\hline \multirow[t]{2}{*}{ Skor12 } & F: TGAACTTAGCATTCCATTC & $(\mathrm{GA})_{10}$ & $253-267$ & JX131661 \\
\hline & R: AAGCGGTTAGACTTTCAGC & & & \\
\hline \multirow[t]{2}{*}{ Skor13 } & F: TTCAATGGGTTATTGGTCC & $(\mathrm{TG})_{14}$ & $238-250$ & JX131662 \\
\hline & R: ATGTATCTTCTGGGACTCG & & & \\
\hline
\end{tabular}

\subsection{Primer Validation}

The microsatellites were characterized for samples from 30 individuals collected in South Korea from Mt. Bibong of Gangwon-do (38 $\left.06^{\prime} 30^{\prime \prime} \mathrm{N}, 17^{\circ} 59^{\prime} 30^{\prime \prime} \mathrm{E}\right)$ and 10 individuals collected in Hanjeon-ri of Gangwon-do $\left(38^{\circ} 08^{\prime} 54^{\prime \prime} \mathrm{N}, 128^{\circ} 00^{\prime} 59^{\prime \prime} \mathrm{E}\right)$. Individuals were collected at $>6-\mathrm{m}$ intervals to avoid sampling a single genet more than once. DNA was extracted according to the method described above, and PCR was conducted with a GeneAmp ${ }^{\circledR}$ PCR System 2700 Thermal Cycler (Applied Biosystems). Each reaction mixture contained $200 \mu \mathrm{M}$ dNTPs (GeneCraft, Lüdinghausen, Germany), 1× PCR buffer with $1.5 \mathrm{mM} \mathrm{MgCl} 2,1 \mathrm{U}$ of Taq DNA polymerase (TaKaRa, Seoul, Korea), $10 \mathrm{ng}$ of DNA, and an appropriate concentration of primers in a total volume of $30 \mu \mathrm{L}$. The mixture also contained a $0.08 \mu \mathrm{M}$ forward M13 (-21)-tagged primer, $0.3 \mu \mathrm{M}$ reverse primer, and $0.3 \mu \mathrm{M}$ M13 (-21)-labeled 6-FAM fluorescent dyes. PCR conditions included an initial denaturation at $94{ }^{\circ} \mathrm{C}$ for $2 \mathrm{~min}$; followed by 38 cycles at $94{ }^{\circ} \mathrm{C}$ for $30 \mathrm{~s}, 52{ }^{\circ} \mathrm{C}$ for $45 \mathrm{~s}$, and $72{ }^{\circ} \mathrm{C}$ for $1 \mathrm{~min}$; with a final extension at $72{ }^{\circ} \mathrm{C}$ for $10 \mathrm{~min}$. Fluorescently labeled PCR products were analyzed concurrently with the GeneScan ${ }^{\text {TM}}-500$ LIZ $^{\text {TM }}$ Size 
Standard (Applied Biosystems) on an ABI 3730xl sequencer, and sizes were determined with GENEMAPPER version 3.7 (Applied Biosystems). Diversity statistics, deviations from Hardy-Weinberg equilibrium (HWE), and linkage disequilibrium (LD) were estimated by GENEPOP version 4.0 software [13]. Null allele frequencies were calculated using MICRO-CHECKER version 2.2.3 [14].

\section{Conclusions}

The 13 microsatellite markers developed in this work are powerful genetic tools for studying populations and establishing effective strategies for management and conservation of Sophora koreensis. We also expect that these markers could provide information about the phylogeography of this species in Korea.

\section{Acknowledgments}

This work was supported by Inha University and the National Research Foundation of Korea (NRF) grant funded by the Korea government (MEST) (No. 2012R1A2A2A01011428).

\section{References}

1. Chung, J.M.; Lee, B.C.; Kim, J.S.; Park, C.W.; Chung, M.Y.; Chung, M.G. Fine-scale structure among genetic individuals of the clone-forming monotypic genus Echinosophora koreensis (Fabaceae). Ann. Bot. 2006, 98, 165-173.

2. Lee, B.C.; Yang, H.O.; Kim, J.S.; Lee, J.K. Rare Plants Data Book in Korea; Korea National Arboretum: Pocheon, Korea, 2008; p. 127.

3. Nakai, T. Genera nova Rhamnacearum et Leguminosarum ex Asia Orientali. Bot. Mag. (Tokyo) 1923, 37, 29-34.

4. Chung, Y.J.; Lee, S.T. A palynotaxonomic study of the Sophora group (Sophoreae, Papilionoideae, Leguminosae). Korean J. Pl. Taxon. 1990, 20, 257-282.

5. Chung, Y.J.; Lee, S.T. Studies on the wing petal morphology of the Sophora group. Korean J. Pl. Taxon. 1991, 21, 37-54.

6. Lee, W.K.; Tokuoka, T.; Heo, K. Molecular evidence for the inclusion of the Korean endemic genus "Echinosophora" in Sophora (Fabaceae), and embryological features of the genus. J. Plant Res. 2004, 117, 209-219.

7. Choi, B.H. Fabaceae Lindl. In The Genera of Vascular Plants of Korea; Flora of Korea Editorial Committee, Eds.; Academy Publishing Co.: Seoul, Korea, 2007; pp. 585-622.

8. Bernardos, S.; Amado, A.; Amich, F. The narrow endemic Scrophularia valdesii Ortega-Olivencia \& Devesa (Scrophulariaceae) in the Iberian Peninsula: an evaluation of its conservation status. Biodivers. Conserv. 2006, 15, 4027-4043.

9. Conner, J.K.; Hartl, D.L. A Primer of Ecological Genetics; Sinauer: Sunderland, MA, USA, 2004; pp. 1-304. 
10. Hammond, R.L.; Saccheri, I.J.; Ciofi, C.; Coote, T.; Funk, S.M.; McMillan, W.O.; Bayes, M.K.; Taylor, E.; Bruford, M.W. Isolation of microsatellite markers in animals. In Molecular Tools for Screening Biodiversity; Karp, A., Isaac, P.G., Ingram, D.S., Eds.; Chapman \& Hall: Weinheim, Germany, 1998; pp. 279-285.

11. Kalendar, R. FastPCR: A PCR Primer and Probe Design and Repeat Sequence Searching Software with Additional Tools for the Manipulation and Analysis of DNA and Protein. Available online: http://www.biocenter.helsinki.fi/bi/programs/fastpcr.htm (accessed on 10 February 2012).

12. Schuelke, M. An economic method for the fluorescent labeling of PCR fragments. Nat. Biotechnol. 2000, 18, 233-234.

13. Rousset, F. GenePop'007: A complete re-implementation of the GenePop software for Windows and Linux. Mol. Ecol. Resour. 2008, 8, 103-106.

14. Van Oosterhout, C.; Hutchison, W.F.; Wills, D.P.M.; Shipley, P. Micro-checker: Software for identifying and correcting genotyping errors in microsatellite data. Mol. Ecol. Notes 2004, 4, 535-538.

(C) 2012 by the authors; licensee MDPI, Basel, Switzerland. This article is an open access article distributed under the terms and conditions of the Creative Commons Attribution license (http://creativecommons.org/licenses/by/3.0/). 